\section{A tribute to Tredegar}

\section{John Launer}

Two people were particularly influential in the creation of the British National Health Service (NHS). One was a politician and the other a doctor and writer. They were entirely different in their backgrounds, politics and temperaments, but their successes complemented each other. By an odd coincidence, they both had connexions with a small town in South Wales called Tredegar. So far as we know, they never met, although their experiences there turned out to be crucial in determining how the NHS took shape. Usually their stories are told separately. They were in fact intertwined.

The better known of the two figures was Aneurin Bevan, the minister of health responsible for the introduction of the NHS in 1948 (see figure 1). Tredegar was his birthplace, and he left school there at 13 to work in the local mines. Later on, in adulthood, he emerged as one of the most significant left-wing politicians in Britain in the twentieth century. ${ }^{1} \mathrm{He}$ was largely self-educated, and overcame a stammer to become a charismatic orator, considered by many as the equal of Winston Churchill with whom he frequently sparred. Bevan continues to be regarded around the world as a pioneer of democratic socialism, and has been voted first among 100 great Welsh heroes.

Bevan sat on the committee of the Workmen's Medical Aid Society in Tredegar and this was a formative experience for him. The society was one of several that were founded in the coal and iron mining towns of South Wales during the late nineteenth century. They were funded by deductions from the wages of local workers in order to support their lifelong medical care and funeral expenses. ${ }^{2}$ Management was organised entirely by the mine workers themselves. By 1933, 95\% of Tredegar's population (including wives, children and retired workers) were covered by the Society, which employed doctors, dentists, pharmacists and nurses, and had its own cottage hospital. When the NHS was founded, Bevan is said to have announced: 'All I am doing is extending to the entire population of Britain the benefits we had in Tredegar for a generation or more. We are going to 'Tredegarise' you.'

Correspondence to Dr John Launer, Postgraduate Medical Journal, London WC1H 9JP, UK; johnlauner@aol.com

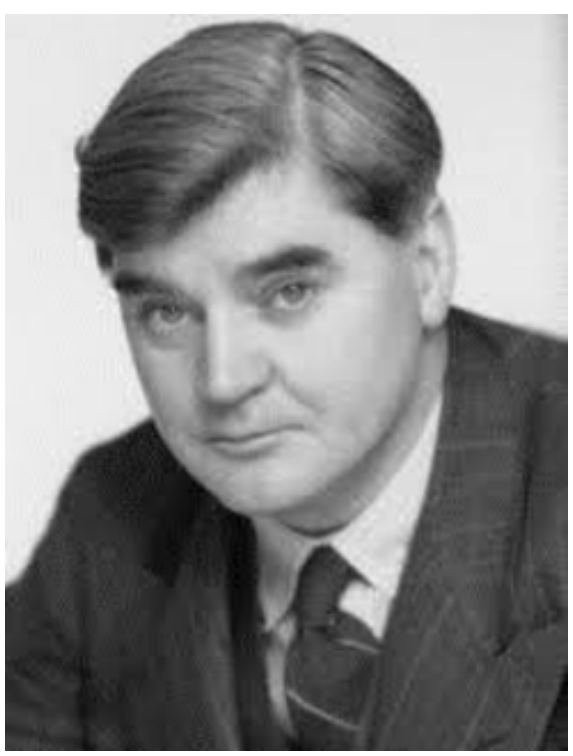

Figure 1 Aneurin Bevan.

The quote attributed to Bevan has led to claims that Tredegar's Medical Aid Society was the template on which the NHS was designed, but this is an oversimplification and not what Bevan stated. Although his years in Tredegar convinced him that healthcare for an entire community was desirable and possible, he became a minister after decades of public debate about a coordinated health service in Britain, culminating in the Beveridge Report in 1942. ${ }^{4}$ It was probably inevitable by then that some kind of nationwide service would be launched. ${ }^{5}$ Bevan actually rejected the proposal that it should be paid for by insurance contributions as it was in the medical aid societies, ${ }^{6}$ or that it should be linked to people's employment. Instead, he insisted on full and direct public funding. For him, the NHS was part of a socialist programme that also encompassed nationalisation of major industries, along with social housing, investment in public amenities, and a tax on land and property. ${ }^{7}$

\section{PUBLIC OPINION}

The other person linking Tredegar with the foundation of the NHS is a more surprising one, and remembered far less. He was a Scottish writer called AJ Cronin (see figure 2). He was one of the most popular authors in Britain at the time. In
1937, he published a novel called 'The Citadel', describing the tribulations of a young doctor as he progressed from working in the South Welsh valleys to the private consulting rooms of Harley Street. ${ }^{8}$ Cronin himself had qualified in medicine in Glasgow just after World War I, and the novel closely parallels his own career. Remarkably, he worked for a while as a general practitioner (GP) for the Workmen's Medical Aid Society in Tredegar, before becoming medical inspector of mines for Great Britain, and then setting up a private practice in London.

Best known for his short stories about Dr Finlay-later the source of a popular television series-Cronin was an unapologetically 'middlebrow' writer, and his prose style has not aged well. It is therefore hard to credit the scale of his influence on public opinion, but it was huge. ' 'The Citadel' sold over 150000 copies in its first 3 months, and 10000 a month for the rest of the year, as well as becoming well known across Europe, USA and the Soviet Union. In a Gallup poll in 1938, it was voted the most interesting book people had ever read, second only to the Bible. ${ }^{10}$ On the strength of the royalties from his books and film rights, AJ Cronin eventually retired to Switzerland as a very wealthy man.

'The Citadel' offered an unsparing portrait of British medicine, from the poorest Welsh cottages to the private consulting suites of London. The physician and writer Seamus O'Mahony has captured Cronin's view as follows:

The medical establishment... is corrupt, venal, unscientific and self-serving. Private practice is shown to be a shabby, money-grabbing business, exploiting the rich and gullible. Quack treatments are commonplace, and most doctors are too lazy to keep themselves abreast of scientific developments. GPs are portrayed as ignorant drudges, peddling useless and outdated drugs. ${ }^{9}$

Cronin's portrayal of the medical aid society in the book is mixed. Its hospital is depicted as decent and well equipped, and some of the working men involved in the appointment and support of doctors are honourable. But he also describes how senior doctors exploited junior ones, how mine workers made what he considered unreasonable requests for sick leave, and how aggrieved patients could conspire to ruin a doctor's career. In spite of Cronin's disclaimer that the people and events are all fictitious, the novel is patently based on his own 


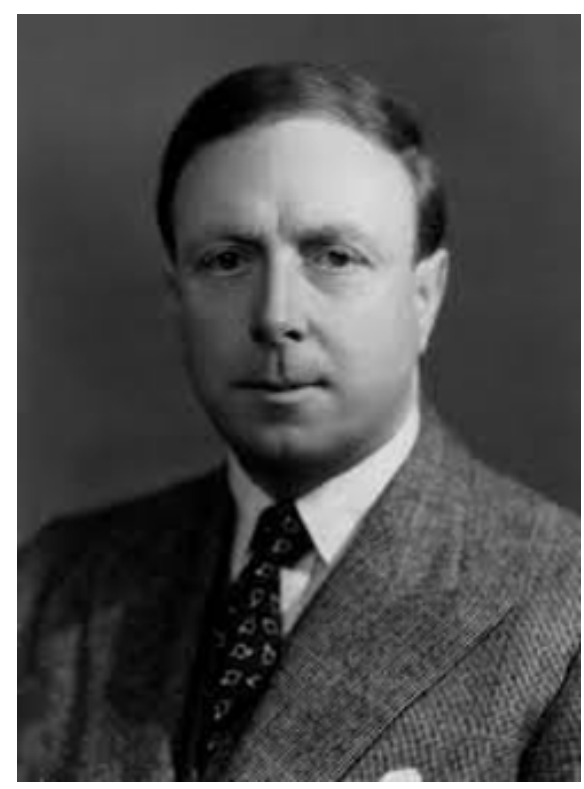

Figure 2 AJ Cronin.

experiences. Indeed, the senior medical officer of the Tredegar Society threatened to sue him for what was clearly an unflattering depiction of himself. ${ }^{11}$

\section{RADICAL IMPROVEMENT}

Cronin was no socialist, and believed that malingering was widespread in the working class. ${ }^{12}$ But his novel arrived at a moment when dissatisfaction with health services in Britain was at its height, and the book fed into the demand for their radical improvement. His publisher, the left-wing Victor Gollancz, was a brilliant publicist, who played on this demand both as a marketing ploy and to promote the same socialist causes as Bevan. ${ }^{13} \mathrm{He}$ used attacks on the novel, especially those of the medical profession on Cronin's portrait of them, as the basis of his publicity. He harnessed 'The Citadel' for a cause that the author himself had not envisaged, but with such impact that Cronin's work, and his critique of British medicine in it, are considered by historians to have played a major part in the victory of the Labour government in 1945 , leading to Bevan's appointment as health minister. ${ }^{14}$ Ironically, the GP who was critical of the workers in Tredegar may have enabled one of them to 'Tredegarise' all of Britain. The NHS is in effect a tribute to Tredegar and the impressions it left on both men.

Acknowledgements The author thanks Dr Steve Thompson of Aberystwyth University/Prifysgol Aberystwyth for providing helpful information and suggestions during the writing of this article.

Funding The authors have not declared a specific grant for this research from any funding agency in the public, commercial or not-for-profit sectors.

Competing interests None declared.

Patient consent for publication Not required.

Provenance and peer review Not commissioned; internally peer reviewed.

(c) Author(s) (or their employer(s)) 2019. No commercial re-use. See rights and permissions. Published by BMJ.

Check for updates
To cite Launer J. Postgrad Med J 2019;95:407-408.

Postgrad Med J 2019;95:407-408.

doi:10.1136/postgradmedj-2019-136853

\section{REFERENCES}

1 Thomas-Symonds N. Nye: The political life of Aneurin Bevan. London: Tauris, 2015.

2 Thompson S. A proletarian public sphere: workingclass self-provision of medical services and care in South Wales, c. 1900-1948. In: Borsay A, ed. Medicine in Wales, c. 1800-2000: public service or private commodity? Cardiff: University of Wales Press, 2003: 86-107.

3 NHS 70: "We will Tredegar-ise the rest of you" South Wales Argus, 2018. Available: https://www. southwalesargus.co.uk/news/16334612.nhs-70-wewill-tredegar-ise-the-rest-of-you/ [Accessed 3 June 2019].

4 Beveridge W. Social insurance and allied service. London: Her Majesty's Stationery Office, 1942.

5 Webster C. The National Health Service; a political history. Oxford: Oxford University Press, 1998

6 The PEP report on the British health services II: National health insurance. BMJ 1938;S37:39-42.

7 Bevan A. In place of fear. London: Heinemann, 1952.

8 Cronin A. The citadel. London: Gollancz, 1937.

9 O'Mahony S. AJ Cronin and the Citadel: did a work of fiction contribute to the foundation of the NHS? J $R$ Coll Physicians Edinb 2012;42:172-8.

10 Gallup AM. The Gallup poll cumulative index: public opinion, 1935-1997. Lanham, MD: Rowman \& Littlefield Publishers, 2009: 135.

11 Davies AAJ. Cronin: the man who created Dr Finlay. Richmond, Surrey: Alma, 2011.

12 Cronin AJ. Adventures in two worlds. London: Gollancz, 1952

13 McKibbin R. The triumph of the medical hero: AJ Cronin's 'The Citadel'. In: McKibbin R, ed. Democracy and Political Culture: Studies in Modern British History. Oxford University Press: Oxford, 2019: 52-76.

14 Samuel R. North and South: a year in a mining village. London Review of Books 1995;17:3-6. 